\title{
Chitosan/whey Protein (CWP) Edible Films Efficiency for Controlling Mould Growth and on Microbiological, Chemical and Sensory Properties During Storage of Göbek Kashar Cheese
}

\author{
Filiz Yangılar \\ Erzincan University Department of Nutrition and Dietetics, 24000, Erzincan/Turkey
}

\begin{abstract}
The objective of present study was to evaluate the effects of the application of chitosan and chitosan/whey protein on the chemical, microbial and organoleptic properties of Göbek Kashar cheese during ripening time (on $3^{\text {rd }}, 30^{\text {th }}, 60^{\text {th }}$ and $90^{\text {th }} \mathrm{d}$ ). Difference in microbiological and chemical changes between samples was found to be significant $(p<0.05)$ during ripening period. Cheese samples with edible coating had statistically lower mould counts compared to the uncoated samples. Furthermore the highest and lowest mould counts were determined in control (4.20 Log CFU/g) and other samples $\left(<1 \mathrm{Log}\right.$ CFU/g) at $60^{\text {th }}$ and $90^{\text {th }} \mathrm{d}$ of storage. All samples exhibited higher levels of water soluble nitrogen and ripening index at the end of storage process. At the end of 90 day storage period, no signicant dierences in salt and fat values were observed among the cheeses studied. The edible coatings had a beneficial effect on the sensory quality of cheese samples. In the result of sensory analysis, while cheese $\mathrm{C}$ and the chitosan coated cheese samples were more preferred by the panellists, the chitosan/whey protein film-coated cheese samples received the lowest scores. This study shows coating suggests could be used to improve the quality of cheese during ripening time.
\end{abstract}

Key words: chitosan, chitosan/whey protein, Göbek Kashar, ripening

Received February 2, 2015 / Revised February 26, 2015 / Accepted February 26, 2015

\section{Introduction}

As a type of cheese, Kashar is manufactured and consumed in an extended geography including Turkey, where the production types and techniques of Kashar may vary depending largely on regions, producers and the methods applied and it has gained great diversity. Among these delicious Kashar cheese types manufactured in certain regions and offering originality is the Göbek Kashar of Ardahan. This type of Kashar is usually produced from cow milk using traditional methods and consumed after a long ripening period changing from 3 mon to 1 year. Göbek Kashar appealing to the taste of local people and containing rich nutrition elements deserves to be the subject of the present study.

Growth of microorganisms on colonization of cheese surfaces is generally seen to be an important risk (Kousta et al., 2010) because such surfaces can allow ideal media

\footnotetext{
*Corresponding author: Filiz Yangılar, Erzincan University Department of Nutrition and Dietetics, 24000, Erzincan/Turkey. Tel: +90-478-211-5000 (2314), Fax: +90-478-211-5000 (3275), E-mail: f_yangilar@hotmail.com
}

for microbial growth by involving efficient amount of water and suitable $\mathrm{pH}$ conditions (Conte et al., 2013). Even though various antimicrobial applications can be done on the surfaces of some types of food using various techniques such as spraying, dipping or brushing in order to take under control microbial growth, such applications are seen to have confined effects (Ture et al., 2011) may be because the antimicrobial effects of the agents used are lost rapidly. The number of studies conducted on the maintenance of food safety and prolong shelf life has increased over the last years. In such studies, edible films to coat foods and enable antimicrobials to remain on the surface are taken into consideration because such films contain active ingredients which can be present at high concentrations where they are needed (Dos Santos Pires et al., 2008; Fajardo et al., 2010; Kristo et al., 2008; Ollé Resa et al., 2013; Ollé Resa et al., 2014; Ture et al., 2011). Furthermore the activites of edible coatings not only depend on the coating methods employed, but also the properties of the coating materials (type, amount, density, viscosity and surface tension) (Zhong et al., 2014).

Food coatings from edible films may contain lipids, proteins, carbohydrates or their combinations and are rep- 
orted to prolong food shelf-life and reduce the rate of hazardous occurrence in food products (Guilbert, 1986; Kester and Fennema, 1986; Krishna et al., 2012; Krochta and Johnston, 1997). From this point of view, the use of an edible film chitosan [poly-a-(1-4)-2-amino-2-deoxy-D-glucose], has been increasingly preferred in recent years. It is a hydrophilic biopolymer from alkaline N-deacetylation of chitin (Kurita, 2001) and exhibits broad-spectrum antimicrobial effects on fungi, bacteria and viruses (Coma et al., 2002; Liu et al., 2001; Rabea et al., 2003; Rhoades and Roller, 2000). Chitosan also can be seen in exoskeletons of crustaceans and insects and in the cell wall of some fungi (Mucoraceae) (Keser and Bilal, 2010) and serve as a protective additive due to its capability of holding fat and water, creating colour, improving durability and exhibiting antibacterial and antifungal characteristics (Gokmen and Gurbuz, 2011; Wang, 1992). In order to prolong shelf life, chitosan was treated on various cheese types as coating by various authors such as Mozzarella (Altieri et al., 2005), Emmental (Coma et al., 2002), Regional Saloio (Cerqueira et al., 2009) and Apulia spreadable cheese (Gammariello et al., 2008). Chitosan was used alone or as carrier of other natural antimicrobials, e.g., lysozyme (Duan et al., 2007), lysozyme and EDTA (Del Nobile et al., 2009).

To the best of authors' knowledge, there has been no study dealing with the effect of chitosan on Göbek Kashar cheese. Therefore, the purpose of this study was to evaluate the effectiveness of using a chitosan and chitosan/whey protein (CWP) coating to prevent mould growth, and to investigate its effects on microbiological, physicochemical properties and proteolysis levels of Göbek Kashar cheese during ripening.

\section{Materials and Methods}

\section{Materials}

Cow milk was picked up from a livestock farm in Göle district, Ardahan province. Microbial rennet (1:15000) was purchased from Mayasan Company, Istanbul, Turkey. Chitosan used for coating Göbek Kashar cheeses was obtained from (Sigma-Aldrich Chemical, USA) and prepared as described by Baxter et al. (1992) with a degree of N-acetylation $9.0 \%$. Spray-dried whey from bovine milk (product no. W1500, lot no. 81K0279), containing $11 \% \mathrm{w} / \mathrm{w}$ proteins (biuret) and $65 \% \mathrm{w} / \mathrm{w}$ lactose was purchased from Sigma Chemical Co. (USA).

\section{Production of Göbek Kashar cheese}

Since no literature could be found about Göbek Kashar cheese, the term "Göbek" was accepted to be used for this local type and it was prepared following the method composed of the experiences of elderly villagers and cheese producers in the province. Cheese samples were produced in a local dairy manufacturer (Alibey plant, Göle, Ardahan). Göbek Kashar cheese was produced traditionally from raw cow milk without starter culture. The raw cow milk $(300 \mathrm{~kg})$ was heated to $32^{\circ} \mathrm{C}$ and rennet diluted in water (1/10) was added for coagulation. After $30 \mathrm{~min}$, the coagulum was cut into cubes and allowed to rest for 15 min. When $\mathrm{pH}$ reached 5.5, whey was removed from curd in the tank and the curd was taken to a vat. Boiling process was conducted at $83^{\circ} \mathrm{C}$ and $5.5 \%$ brine. Boiled cheese paste was cut into pieces in moulding machine at 75 to $83^{\circ} \mathrm{C}$, desired weight and put into moulds. After resting in mould for $10 \mathrm{~min}$, mould was removed and past was expanded. After resting for an additional $10 \mathrm{~min}$ out of mould, Göbek Kashar cheese was taken on a wooden bench. Cheese samples were stored on benches for 10 hours at room temperature and then additional 10 hours at 10 to $15^{\circ} \mathrm{C}$. Göbek Kashar cheese, a traditional cheese type, gets its name from its shape (göbek means belly in Turkish) and manufacturing process is given in Fig. 1.

Following the preripening process, cheese samples were divided into three groups; control $(\mathrm{C}$; without edible films), chitosan (X; 0.8\% w/v) and chitosan/whey protein $(0.8 \% \mathrm{w} / \mathrm{v}$ chitosan and $2.4 \% \mathrm{w} / \mathrm{v}$ lyophilized milk whey; $\mathrm{Y})$. Cheese samples were first analysed at the end of preripening process and before coating. Other analyses were carried out in $30 \mathrm{~d}$ intervals (i.e., on $3^{\text {rd }}, 30^{\text {th }}, 60^{\text {th }}$ and $90^{\text {th }}$ d) by duplicating all the analyses.

\section{Preparation of chitosan/whey protein film forming solution}

A CWP film forming solution, containing $0.8 \% \mathrm{w} / \mathrm{v}$ chitosan and $2.4 \% \mathrm{w} / \mathrm{v}$ lyophilized milk whey (11\% WP), was prepared by mixing of chitosan dissolved in $0.1 \mathrm{~N}$ $\mathrm{HCl}$ and lyophilized milk whey dissolved in distilled water under continuous stirring. The $\mathrm{pH}$ of the chitosanwhey solution was adjusted to $\mathrm{pH} 5.0$ with $0.1 \mathrm{~N} \mathrm{HCl}$, and the solution was filter-sterilized. Films were prepared by casting $32.5 \mathrm{~mL}$ of either chitosan $(0.8 \% \mathrm{w} / \mathrm{v})$ or CWP $(0.8 \% \mathrm{w} / \mathrm{v}$ chitosan and $2.4 \% \mathrm{w} / \mathrm{v}$ lyophilized milk whey) solutions into polystyrene petri dishes $(60 \times 15 \mathrm{~mm})$ and in the preparation of coating films was used method as in the study of Di Pierro et al. (2010).

\section{Microbiological analysis}

Dried coating solution was removed from each cheese 


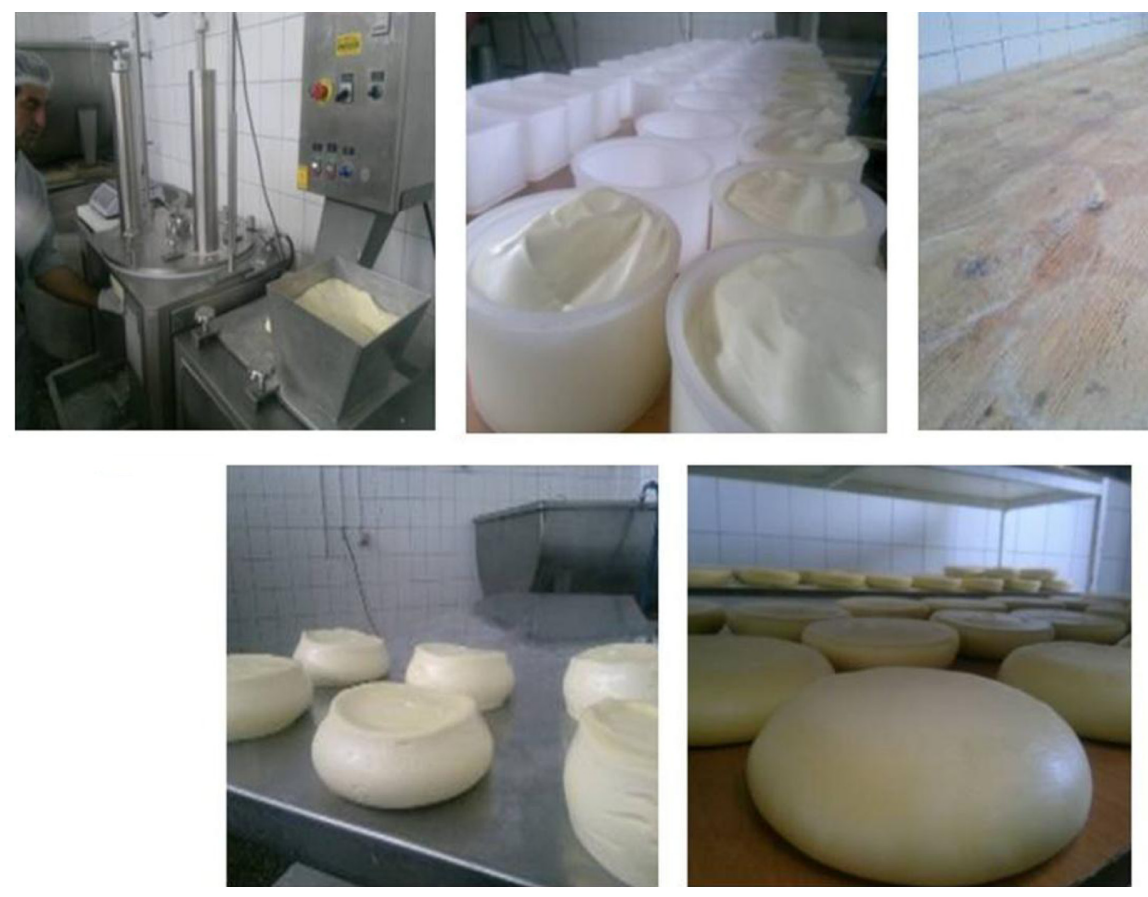

Fig. 1. The production of Göbek Kashar cheese.

wheel using sterile gloves and the sample groups were subjected to microbiological analysis. For each sample, $11 \mathrm{~g}$ cheese was taken and diluted in $99 \mathrm{~mL}$ of $0.85 \%$ (wt/vol) sterile saline solution. After that, a Stomacher (Lab. Stomacher Blander 400 BA 7021, Swardmedical) was used to homogenise the samples in a sterile polyethylene bag for $1.5 \mathrm{~min}$. Sterile $9 \mathrm{~mL} 0.85 \%$ (wt/vol) $\mathrm{NaCl}$ was used for dilution and the number of total aerobic mesophilic bacteria (TAMB; Merck, at $30 \pm 1^{\circ} \mathrm{C}$ for $72 \mathrm{~h}$; Ozdemir and Sert, 1996); lactic acid bacteria (in MRS; Merck, at $30^{\circ} \mathrm{C}$ for $48 \mathrm{~h}$ in anaerobic conditions; Diliello, 1982); lactic acid bacteria (in M17; Merck, at $30^{\circ} \mathrm{C}$ for 48 h; Sert et al., 2007); coagulase-positive Staphylococcion Baird-Parker agar with egg yolk tellurite enrichment (Merck, at $37^{\circ} \mathrm{C}$ for $24 \mathrm{~h}$; Ozdemir and Sert, 1996); coliforms (Violet Red Bile Agar, Oxoid, at $35 \pm 2^{\circ} \mathrm{C}$ for $48 \mathrm{~h}$; Diliello, 1982) and moulds (Potato Dextrose Agar, Oxoid, at $25^{\circ} \mathrm{C}$ for 5 to $7 \mathrm{~d}$; Koburger and Marth, 1984) were counted.

\section{Chemical Analysis}

After the removal of coating materials, each of cheese samples was fully shredded. Parameters of moisture, fat, salt and titratable acidity (by titration method with $\mathrm{NaOH}$ using phenolphthalein as an indicator) were measured conveniently with the method of Kurt et al. (2007). Kjeldahl method (International Dairy Federation, 1993) was used to determine total nitrogen (TN) while $\mathrm{pH}$ was measured using a pH-metre (WTW 340-1) as in the study of Savello et al. (1989).

\section{Nitrogen fractions}

Water-soluble nitrogen (WSN), $12 \%$ trichloroacetic acidsoluble nitrogen (TCA-SN) and $\mathrm{pH}$ 4.6-soluble- nitrogen in the percentage of cheese were determined in the aliquots of the same cheese extract prepared as described by Kuchroo and Fox (1982). A 20 g grated cheese sample was homogenised in $40 \mathrm{~mL} \mathrm{H} \mathrm{H}_{2} \mathrm{O}$ for $2 \mathrm{~min}$ through an Ultra turrax blender (IKA, USA); stored at $40^{\circ} \mathrm{C}$ for $1 \mathrm{~h}$; centrifuged at $3000 \mathrm{~g}$ for $30 \mathrm{~min}$ at $4^{\circ} \mathrm{C}$; its fatty layer was removed and the supernatant was filtered with filter paper (Whatman 113). Twenty five $\mathrm{mL}$ extract prepared for WSN was taken at an equal volume of $24 \%$ (wv) and TCA was added for further fractionation of the nitrogenous compounds. The mixtures were incubated for $2 \mathrm{~h}$ at room temperature. Precipitates were filtered through filter paper (Polychroniadou et al., 1999). Contents of WSN, TCA-SN and $\mathrm{pH}$ 4.6-SN were determined by Kjeldahl method. The ripening index (RI) was determined using the formula WSN/ TN $\times 100$.

\section{Sensory evaluation}

Eight panellists experienced in the sensorial evaluation of Göbek Kashar cheese assessed the cheese samples on 
$3^{\text {rd }}, 30^{\text {th }}, 60^{\text {th }}$ and $90^{\text {th }} \mathrm{d}$ of ripening considering the method of Bodyfelt et al. (1988) and modifying the sensory criteria for the characteristics of Göbek Kashar cheese. Samples were scored considering five sensorial features e.g., colour-appearance, texture, taste, odour and general acceptability ranging from 1 (poor) to 9 (excellent).

\section{Statistical analysis}

The experimental design consisted of completely randomised design in a factorial arrangement: three treatments of Kashar cheese ( $\mathrm{C}, \mathrm{X}$ and $\mathrm{Y}$ ), four ripening time $(3,30,60$ and $90 \mathrm{~d})$ and two replicates. All statistical calculations were performed using SAS Statistical Software (SPSS 17.0, USA; SAS, 1998). Duncan's multiple range tests and variance analysis were used to evaluate the significance level $(p<0.05)$ for statistical differences.

\section{Results and Discussion}

Dry matter, fat and proteincontents and acidity, SH and $\mathrm{pH}$ rates of the cow milk used in the manufacturing process of Göbek Kashar cheese samples were $12.71 \pm 0.28 \%$, $3.5 \pm 1.24 \%, 3.21 \pm 0.11 \%, 5.8 \pm 0.04$ and $6.52 \pm 0.07$, respectively while the counts of TAMB, LAB in MRS, LAB in M17, coliform bacteria and moulds of the milk used in the production of Kashar cheeses were $8.15 \pm 0.03,7.31 \pm$ $0.27,6.5 \pm 0.51,4.73 \pm 0.80$ and $4.6 \pm 0.25 \mathrm{Log}$ CFU/g, respectively.

\section{Microbiological evaluation}

Results of the microbiological analysis carried out over cheese samples are given in Fig. 2 (a)-(e). Microbiological counts in cheese samples were found to be significant $(p<0.05)$ during ripening period. TAMB counts of C samples were determined to be higher than the others. As can be seen in Fig. 2(a), total number of mesophilic aerobic bacteria in cheese samples was determined to range in cheese from 7.20 to $8.14 \mathrm{Log}$ CFU/g. Similar results were obtained by several researchers (Sarıoglu and Oner, 2006; Yıýlmaz and Dagdemir, 2012). Fajardo et al. (2010) found mesophilic bacteria counts to be between 6.29 and 7.51 Log CFU/g in natamycin coated Saloio cheese. Lucera et al. (2014) stated the total bacterial counts showed an increasing trend in fresh mozzarella cheese. The initial microbial count was about $4.5 \mathrm{Log} \mathrm{CFU} / \mathrm{g}$, and in the control samples slightly faster than in the other cheese coated with potassium sorbate. Such results found in previous studies aren't in convenience with the present study.
Counts of LAB in MRS were determined in cheese samples to range between 6.23 and $7.76 \mathrm{Log} \mathrm{CFU} / \mathrm{g}$ which were found to be significantly lower $(p<0.05)$ in control samples on $3^{\text {rd }}$ and $30^{\text {th }}$ days of ripening by closing as the values measured for coated samples. These results were found to be in convenience with the values found in previous studies (Y1lmaz and Dagdemir, 2012). Di Pierro et al. (2011) found lactic acid bacteria (MRS) to be in the range of 5 to $6 \mathrm{Log} \mathrm{CFU} / \mathrm{g}$ for the control on $14^{\text {th }} \mathrm{d}$ and for the chitosan/whey protein film-coated cheese samples on $30^{\text {th }} \mathrm{d}$, which are lower than the findings in the present study. As can be seen in Fig. 2(c), the LAB (M17) values were found in cheese samples to be between 5.84 and 7.25 Log CFU/g. Y1lmaz and Dagdemir (2012) found high results to be between 6.73 and 8.13 for $120 \mathrm{~d}$ of coated beewax coated Kashar cheese samples. These results showed that coating with chitosan and CWP did not have any negative influences on the growth of necessary microorganisms for the maturation of cheese.

The treatment and storage processes were found to affect significantly the moulds $(p<0.05)$ in cheese samples in the present study being between $<1$ and $4.15 \mathrm{Log}$ CFU/ g. Microbiological analyses showed that samples coated with chitosan and CWP exhibited a decrease on moulds compared to control after $90 \mathrm{~d}$ of storage while $\mathrm{X}$ represented higher mould counts than the sample $\mathrm{Y}$ at the end of ripening period. Similar results were reported by several studies (Sarıoglu and Oner, 2006; Y1lmaz and Dagdemir, 2012). Mould counts were reported to be $10^{2} \mathrm{CFU} /$ $\mathrm{g}$ for all samples in Y1lmaz and Dagdemir (2012) while increasing for control sample from 2.75 to $4.60 \mathrm{Log}$ $\mathrm{CFU} / \mathrm{g}$ in the storage period and from $15^{\text {th }} \mathrm{d}$ of ripening. Sarioglu and Oner (2006) stated that mould and yeast could not be counted in Na-caseinate film coated Kashar cheese samples from $60^{\text {th }} \mathrm{d}$ while in uncoated samples counting could not be done from $90^{\text {th }} \mathrm{d}$. Fajardo et al. (2010) reported the counts of mould and yeast to be 4.53 and $6.06 \mathrm{Log}(\mathrm{CFU} / \mathrm{g})$, respectively and that on $27^{\text {th }} \mathrm{d}$ of storage, natamycin+chitosan coated cheese presented lower mould/yeast rate (4.95 \pm 0.27$)$. Ramos et al. (2012) studied the efficacy of edible films produced from whey protein isolate, glycerol and natamycin as antimicrobial agent. The authors showed through the viable cell counts assay that natamycin incorporated in the film displayed a cidal effect against Y. lipolytica. Balaguer et al. (2013) observed no fungi in the cheese samples packaged with the active film on $26^{\text {th }} \mathrm{d}$ of storage at $4{ }^{\circ} \mathrm{C}$ while there was fungi growth in control samples on $16^{\text {th }} \mathrm{d}$ of storage. Ollé Resa et al. (2014) studied the effectiveness of natamycin 

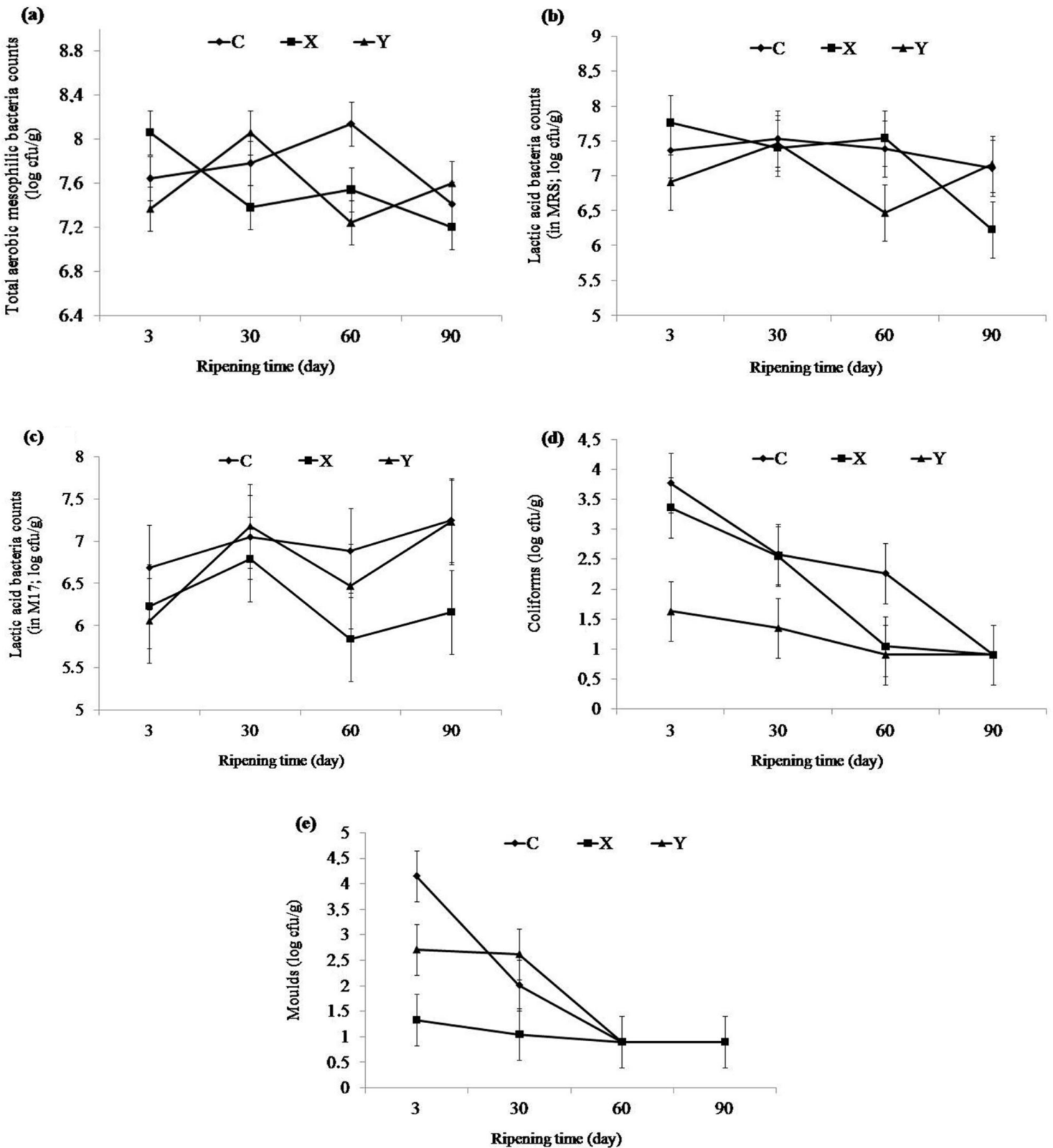

Fig. 2. The changes in microbiology characteristics of Göbel Kashar cheese samples (a) total aerobic mesophilic bacteria; (b) lactic acid bacteria (in MRS agar), (c) lactic acid bacteria (in M17 agar); (d) coliforms and (e) moulds (Log CFU/g).

against yeast in Port Salut cheese and exerted an initial fungicidal effect against $S$. cerevisiae. The barrier test performed in cheese with films Cas $/ \mathrm{N}$ which means that the edible film exerted a fungicidal effect against moulds. Additionally coated materials prevented the contamination of the cheese by the microorganisms inoculated in the dipping.

Counts of coliform bacteria were found in cheese samples to be between $<1$ and $3.77 \mathrm{Log} \mathrm{CFU} / \mathrm{g}$ in the present study while it was $<1 \mathrm{Log}$ CFU/g level in Y1lmaz and Dagdemir (2012). Sarıoglu and Oner (2006) stated that counts of coliform microorganisms could not be detected in Na-caseinate film coated Kashar cheese on $90^{\text {th }} \mathrm{d}$ while it was possible to count them in control samples on $60^{\text {th }} \mathrm{d}$. Staphylococcus aureus count was under detectable level (2 Log CFU/g) in all samples during ripening which can be attributed to the scalding process applied in the production of Göbek Kashar cheese. Pranoto et al. (2005) determined the inhibitor effect of antimicrobial alginate film containing $0.4 \%$ garlic oil on S. aureus. Torlak and Nizamoglu (2011) reported in Kashar cheese samples coated with renewable films that the counts of $S$. aureus 
decreased on $14^{\text {th }} \mathrm{d}$ compared to control group between 0.90-2.66 Log and all the film types exhibited antimicrobial effect at significant level compared to control group $(p<0.05)$. Furthermore Mei et al. (2013) reported that the application of starch-chitosan film's in the storage of Mongolian cheese for controlling microbial populations was effective.

\section{Chemical conclusion}

Chemical composition of the cheese samples is given in Table 1. Chemical changes in samples were found to be statistically significant $(p<0.05)$ during ripening period on $90^{\text {th }} \mathrm{d}$. Dry matter of the samples was found to change between 57.70 and $64.18 \%$. This increase was higher for the cheese samples without coating $(p<0.05)$. These results may show that the coating process with chitosan and CWP might have delayed moisture losses compared to control. Fajardo et al. (2010) reported the moisture content of coated Saloio cheese before storage to be significantly higher than that of uncoated cheese samples resulting mainly from the water content of the coating itself while this difference was valid at $4^{\circ} \mathrm{C}$ only for natamycin + chitosan coated cheese samples. Y1ldirım et al. (2006) found that the dry matter content of Kashar cheese samples A (control), C (coating with casein solution), D (coating with casein solution containing natamycin) and $\mathrm{E}$ (dipping in natamycin solution) increased until the $60^{\text {th }} \mathrm{d}$ of storage $(p<0.05)$ after which it did not change significantly $(p>0.05)$.

In the present study, similar to the total dry matter content, the fat content in all the cheese samples increased with increasing ripening time $(p<0.05)$. The lowest fat content was observed in sample Y $(26.22 \%$, w/w) while the highest in C $(30.30 \%)$. In coated Kashar cheese samples, the lowest and highest fat rates were $31.37 \%$ and $43.25 \%$ while in control group they were $30.5 \%$ and 42.25\% (Sar1oglu and Oner, 2006). Similar results were obtained by Yildirim et al. (2006). Salt values were found in samples to be between 3.50 and $5.75 \%$. Gulec et al. (2004) found the lowest and the highest salt rates of casein coated Kashar cheese samples and control to be $1.54 \%$ to $2.54 \%$ and $1.54 \%$ to $2.43 \%$.

As can be seen in Table 1, the treatment and storage affected significantly $\mathrm{pH}$ values $(p<0.05)$. Gulec et al. (2004) stated that $\mathrm{pH}$ ranged from 5.14 to 5.25 in casein coated and uncoated Kashar cheese samples on $90^{\text {th }}$ of storage, which are in convenience with the present study. Lucera et al. (2014) determined pH of mozzarella cheese, monitored during the entire observation period, ranged between 6.50 and 6.30 .

Acidity rates of the samples varied between 21.01 and 35.46 SH. Di Pierro et al. (2011) reported that titratable acidity of Ricotta cheese, coated with a chitosan/whey protein film, reached the same level as measured for the control sample at the end of storage.

In the present study, protein rates of the samples were between 25.12 and $28.06 \%$. Gulec et al. (2004) reported the lowest and highest rates of protein in cheese samples and control Kashar samples to be 24.5 to $31.36 \%$ and 24.5 to $31.28 \%$ while Sarýoglu and Oner (2006) found this rate in Kashar samples and control group to be 27.70 to $36.64 \%$ and 27.25 to $34.40 \%$, respectively. WSN values increased during ripening period. Y1lmaz and Dagdemir (2012) found WSN to be significantly higher in control

Table 1. The changes in chemical characteristics of Göbek Kashar cheeses during ripening

\begin{tabular}{|c|c|c|c|c|c|c|c|c|c|c|c|}
\hline $\begin{array}{l}\text { Cheese } \\
\text { samples }\end{array}$ & $\begin{array}{l}\text { Ripening } \\
\text { time (d) }\end{array}$ & $\begin{array}{c}\text { Dry matter } \\
(\%)\end{array}$ & Fat (\%) & Salt (\%) & $\mathrm{pH}$ & $\begin{array}{c}\text { Acidity } \\
\text { SH }\end{array}$ & $\begin{array}{c}\text { Protein } \\
(\%)\end{array}$ & $\begin{array}{c}\text { WSN } \\
(\%)\end{array}$ & $\begin{array}{l}\text { Ripening } \\
\text { index }(\%)\end{array}$ & $\begin{array}{c}\text { TCA-SN } \\
(\%)\end{array}$ & $\begin{array}{c}\mathrm{pH} 4.6-\mathrm{SN} \\
(\%)\end{array}$ \\
\hline & 3 & $59.22 \pm 0.51^{\mathrm{b}}$ & $27.30 \pm 0.32^{b}$ & $4.18 \pm 0.17^{b}$ & $5.85 \pm 0.03^{\mathrm{c}}$ & $21.01 \pm 0.02^{\mathrm{a}}$ & $26.74 \pm 0.03^{\mathrm{a}}$ & $3.93 \pm 0.03^{b}$ & $14.71 \pm 0.12^{b}$ & $4.54 \pm 0.30^{\mathrm{a}}$ & $6.52 \pm 0.24^{b}$ \\
\hline & 30 & $60.70 \pm 0.7$ & $28.60 \pm 0.16^{\mathrm{c}}$ & $4.70 \pm 0.25^{\mathrm{a}}$ & $5.66 \pm 0.06^{\mathrm{a}}$ & $23.27 \pm 0.06^{\mathrm{a}}$ & $26.35 \pm 0.03^{\mathrm{a}}$ & $4.10 \pm 0.02^{b}$ & $15.57 \pm 0.09^{c}$ & $5.91 \pm 0.05^{\mathrm{a}}$ & $6.97 \pm 0.18^{b}$ \\
\hline & 60 & $62.54 \pm$ & & 5.49 & $5.49 \pm 0.06^{\mathrm{b}}$ & $27.94 \pm 0.02^{\mathrm{a}}$ & $25.87 \pm 0.55^{\mathrm{a}}$ & $4.67 \pm 0.04^{\mathrm{a}}$ & $18.07 \pm 0.20^{\mathrm{b}}$ & $6.81 \pm 0.15^{\mathrm{a}}$ & $7.62 \pm 0.14^{b}$ \\
\hline & 90 & $64.18 \pm 0$ & & & $5.34 \pm$ & $30.14 \pm 0.09^{\mathrm{a}}$ & $25.32 \pm 0.23^{\mathrm{a}}$ & $5.34 \pm 0.04^{b}$ & $21.11 \pm 0.12^{\mathrm{b}}$ & $7.62 \pm 0.20^{\mathrm{a}}$ & $8.69 \pm 0.30^{b}$ \\
\hline & 3 & $57.70 \pm 0.24^{\mathrm{a}}$ & 26.27 & $3.50 \pm 0.10^{\mathrm{a}}$ & $5.53 \pm 0.03^{b}$ & $22.32 \pm 0.02^{\mathrm{b}}$ & $27.49 \pm 0.07^{\mathrm{c}}$ & $3.42 \pm 0.03^{\mathrm{a}}$ & $12.45 \pm 0.10^{\mathrm{a}}$ & $6.22 \pm 0.74^{b}$ & $7.55 \pm 0.35^{\mathrm{c}}$ \\
\hline & 30 & $58.43 \pm 0$ & & & $37 \pm 0.36^{\mathrm{a}}$ & $25.67 \pm 0.04^{\mathrm{b}}$ & $26.57 \pm 0.06^{\mathrm{b}}$ & $3.63 \pm 0.03^{\mathrm{a}}$ & $13.66 \pm$ & $6.75 \pm 0.10^{b}$ & $7.22 \pm 0.11^{\mathrm{c}}$ \\
\hline & 60 & $60.52 \pm 0.20^{\mathrm{b}}$ & & $5.04 \pm 0.02^{\mathrm{a}}$ & $5.20 \pm 0.19^{\mathrm{a}}$ & $28.65 \pm 0.08^{\mathrm{b}}$ & $26.98 \pm 0.22^{\mathrm{b}}$ & $4.78 \pm 0.09^{b}$ & $17.71 \pm 0.19^{\mathrm{a}}$ & $7.47 \pm 0.08^{b}$ & $9.21 \pm 0.08^{\mathrm{c}}$ \\
\hline & 90 & $61.24 \pm 0.18^{\mathrm{b}}$ & $29.07 \pm 0.06^{\mathrm{a}}$ & $5.37 \pm 0.06^{\mathrm{a}}$ & $5.14 \pm 0.02^{\mathrm{a}}$ & $31.16 \pm 0.04^{\mathrm{b}}$ & $25.12 \pm 0.09^{\mathrm{a}}$ & $5.01 \pm 0.11^{\mathrm{a}}$ & $19.95 \pm 0.47^{\mathrm{b}}$ & $8.09 \pm 0.02^{\mathrm{c}}$ & $9.01 \pm 0.02^{\mathrm{c}}$ \\
\hline & 3 & $58.09 \pm 0.78^{\mathrm{a}}$ & $26.22=$ & $4.38 \pm$ & $5.42 \pm$ & $29.15 \pm 0.04^{\mathrm{c}}$ & $27.20 \pm 0.11^{b}$ & $4.21 \pm 0.71^{\mathrm{c}}$ & $15.33 \pm 0.43^{\mathrm{c}}$ & $6.25 \pm 0.03^{b}$ & $4.25 \pm 0.05^{\mathrm{a}}$ \\
\hline & 30 & $58.80 \pm 0.10^{\mathrm{a}}$ & 27.46 & $4.43 \pm 0.13^{\mathrm{a}}$ & $5.36 \pm 0.04^{\mathrm{a}}$ & $32.66 \pm 0.13^{\mathrm{c}}$ & $28.06 \pm 0.03^{\mathrm{c}}$ & $4.17 \pm 0.11^{b}$ & $14.10 \pm 0.09^{b}$ & $6.00 \pm 0.14^{\mathrm{a}}$ & $5.83 \pm 0.08^{\mathrm{a}}$ \\
\hline & 60 & $59.80 \pm 0.13^{\mathrm{a}}$ & 28.10 & $5.45 \pm($ & $5.28 \pm 0.02^{\mathrm{a}}$ & $35.46 \pm 0.34^{\mathrm{c}}$ & $26.61 \pm 0.11^{\mathrm{b}}$ & $5.16 \pm 0.03^{\mathrm{c}}$ & $19.40 \pm 0.14^{\mathrm{c}}$ & $7.46 \pm 0.06^{\mathrm{b}}$ & $6.04 \pm 0.02^{\mathrm{a}}$ \\
\hline & 90 & $60.31 \pm 0.04^{\mathrm{a}}$ & $29.60 \pm 0.01^{\mathrm{b}}$ & $5.75 \pm 0.16^{\mathrm{b}}$ & $5.22 \pm 0.02^{\mathrm{b}}$ & $34.57 \pm 0.23^{\mathrm{c}}$ & $27.31 \pm 0.68^{b}$ & $5.12 \pm 0.02^{\mathrm{ab}}$ & $18.66 \pm 1.15^{\mathrm{a}}$ & $7.87 \pm 0.08^{b}$ & $6.46 \pm 0.12^{\mathrm{a}}$ \\
\hline
\end{tabular}

* Mean values followed by different letters in the same column are significantly different $(p<0.05)$.

Control (C. without edible films); X. chitosan $(0.8 \% \mathrm{w} / \mathrm{v})$; Y. chitosan/whey protein $(\mathrm{CWP}, 0.8 \% \mathrm{w} / \mathrm{v}$ chitosan and $2.4 \% \mathrm{w} / \mathrm{v}$ lyophilized milk whey). 
cheese until day 120, followed by BW1 (single-layer coating). The ripening index value ranged from 14.71 to $21.11 \%$ for control sample and 12.45 to $19.95 \%$ for $\mathrm{X}$ and 14.10 to $18.66 \%$ for Y. Yıldırım et al. (2006) reported that the ripening index of Kashar cheese samples increased steadily until the $60^{\text {th }} \mathrm{d}$ of ripening. Gulec et al. (2004) found ripening index values of all samples were similar until $60^{\text {th }} \mathrm{d}$ while on $90^{\text {th }} \mathrm{d}$, ripening index values of control increased more than coated samples. The coating method used significantly affected the ripening of cheese. As can be seen in Table 1, 12\% TCA-SN content in the cheese samples increased with increasing ripening time $(p<0.05)$. The values of $12 \%$ TCA-SN, expressed as $\%$, showed a significant increase $(p<0.05)$ during ripening process (Y1lmaz and Dagdemir, 2012). Aydemir (2010) reported that the increase in WSN\%TN and TCA\%TN values was low when the Kashar cheese samples were ripened at $4 \pm 1{ }^{\circ} \mathrm{C}$ following the pre-ripening. The $\mathrm{pH}$ 4.6SN ranged from 6.52 to $8.69 \%$ for the control samples, 7.22 to $9.21 \%$ for $\mathrm{X}$ and 4.25 to $6.46 \%$ for $\mathrm{Y}$ was significant $(p<0.05)$ during ripening time. The values of $\mathrm{pH}$ 4.6-SN were found to be $10.72-23.76 \%$ in the sample of Kashar cheese samples in Hayaloglu (2009).

\section{Sensory evaluation}

Results of the sensory evaluation of 90 day cheese samples on a scale from 1 (poor) to 9 (excellent) are shown in a radar plot in Fig. 3. A significant difference $(p<0.05)$ was found to be between the samples for colour-appearance, taste, texture, odour and general acceptability. C sample was preferred the most by the panellists. Y sample was given the lowest scores by the panellists. Yıldirım et al. (2006) reported lower texture and taste scores of vac- uum-packaged Kashar cheese compared to control and those coated with casein. Di Pierro et al. (2011) stated that compared to control, Ricotta cheese exhibited better texture conditions when it was coated with chitosan/whey protein film while no difference was found to be in visual appearance, texture, flavour and odour between uncoated and chitosan/whey protein film coated Ricotta cheese samples. Cetinkaya et al. (2004) reported significant differences between Kashar samples coated with beewax in terms of aroma, flavour, o colour, appearance and texture.

Coating of Göbek Kashar cheese with edible film composed of chitosan and chitosan/whey protein showed reducing effect on the microbial growth and extended the shelf-life of the products. It is indicated from the results that the use of chitosan/whey protein can suppress mould growth during the ripening time without any adverse effects on cheese quality. During the ripening process of cheese, the level of soluble nitrogen components determined the effect of the edible film coating on the rate and extent of proteolysis quantitatively in cheese. In terms of sensorial evaluation, panellists gave the highest scores especially to $\mathrm{C}$ group. This study may be important since it could indicate successfully through the coated samples with chitosan and chitosan/whey protein that the mentioned materials could be used as good coating materials in the manufacture of Göbek Kashar cheese and extended throughout this cheese production to improve quality.

\section{References}

1. Altieri, C., Scrocco, C., Sinigaglia, M., and Del Nobile, M. A. (2005) Use of chitosan to prolong mozzarella cheese shelf life. J. Dairy Sci. 88, 2683-2688.

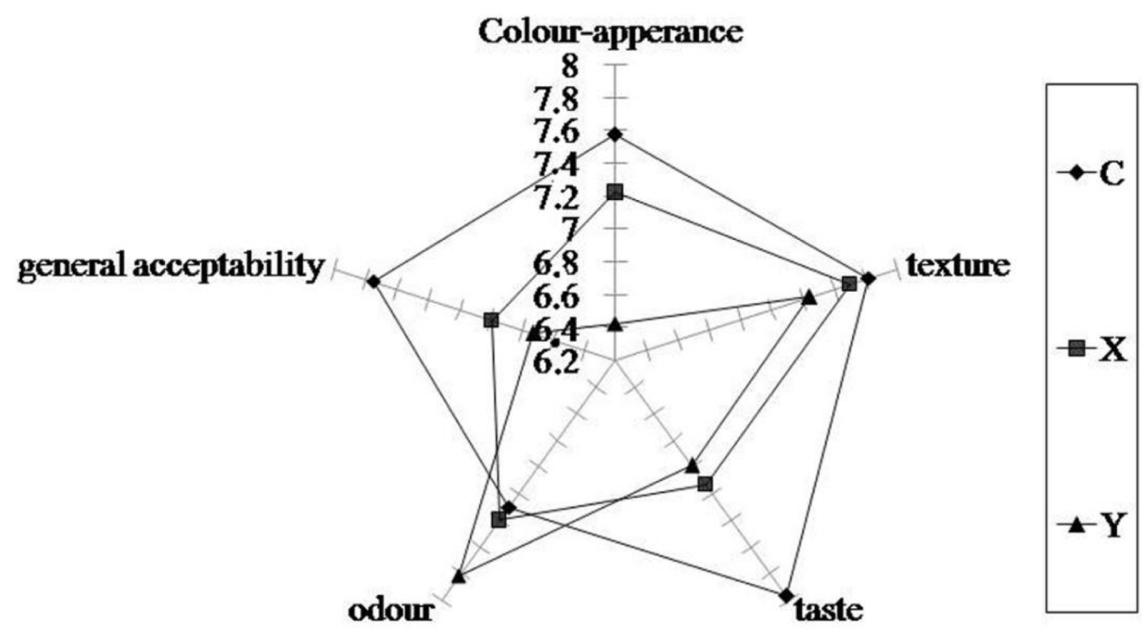

Fig. 3. Changes in sensory characteristics of Göbek Kashar cheese after $90 \mathrm{~d}$ of storage. 
2. Aydemir, O. (2010) The Characterization of Kars Kashar Cheese. PhD Thesis. Ondokuz Mayýs University, Graduate School of Natural and Applied Sciences Samsun, Turkey

3. Balaguer, M. P., Lopez-Carballo, G., Catala, R., Gavara, R., and Hernandez-Munoz, P. (2013) Antifungal properties of gliadin films incorporating cinnamaldehyde and application in active food packaging of bread and cheese spread foodstuffs. Int. J. Food Microbiol. 166, 369-377.

4. Baxter, A., Dillon, M., Taylor, K. D. A., and Roberts, G. A. F. (1992) Improved method for IR determination of the degree of N-acetylation of chitosan. Int. J. Biol. Macromol. 14, 166-169.

5. Bodyfelt, F. W., Tobias, J., and Trout, G. M. (1988) The sensory evaluationof dairy products. New York: Published by Van NastrandReinhold.

6. Cerqueira, M. A., Lima, A. M., Souza, B. W. S., Teixeira, J. A., Moreira, R. A., and Vicente, A. A. (2009) Functional polysaccharides as edible coatings for cheese. J. Agr. Food Chem. 57, 1456-1462.

7. Cetinkaya, F. and Soyutemiz, G. E. (2004) A study on survival of listeria monocytogenes during manufacture and ripening of Kashar cheese. Turk. J. Vet. Anim. Sci. 28, 927-932.

8. Coma, V., Martial-Gros, A., Garreau, S., Copinet, A., Salin, F., and Deschamps, A. (2002) Edible antimicrobial films based on chitosan matriz. J. Food Sci. 67,1162-1169.

9. Conte, A., Angiolillo, L., Mastromatteo, M., and Del Nobile, A. (2013) Technological options of packaging to control food quality. Food Ind. pp. 354-379.

10. Del Nobile, M. T., Gammariello, D., Conte, A., and Attanasio, M. (2009) A combination of chitosan, coating and modified atmosphere packaging for prolonging Fior dilatte cheese shelf life. Carbohydr. Polym. 78, 151-156.

11. Diliello, L. R. (1982) Methods in food and dairy microbiology. AVI Publishing Co. Inc.

12. Di Pierro, P., Mariniello, L., Sorrentino, A., Villalonga, R., Chico, B., and Porta, R. (2010) Putrescine-polysaccharide conjugates as transglutaminase substrates and their possible use in producing crosslinked films. Amino Acids 38, 669-675.

13. Di-Pierro, P. D., Sorrentino, A., Mariniello, L., Giosafatto, C. V. L., and Porta, R. (2011) Chitosan/whey protein film as active coating toextend Ricotta cheese shelf-life. LWT-Food Sci. Technol. 44, 2324-2327.

14. Dos Santos Pires, A. C., De Fátima Ferreira Soares, N., De Andrade, N. J., Da Silva, L. H. M., Camilloto, G. P., and Bernardes, P. C. (2008) Development and evaluation of active packaging for sliced mozzarella preservation. Packag. Technol. Sci. 21, 375-383.

15. Duan, J., Park, S. I., Daeschel, M. A., and Zhao, Y. (2007). Antimicrobialchitosan Lysozyme (CL) films and coatings for enhancingmicrobial safety of Mozzarella cheese. Food Microbiol. Safety 72, 355-361.

16. Fajardo, P., Martins, J. T., Fuciños, C., Pastrana, L., Teixeira, J. A., and Vicente, A. A. (2010). Evaluation of a chitosanbased edible film as carrier of natamycin to improve the storability of Saloio cheese. J. Food Eng. 101, 349-356.

17. Gammariello, D., Chillo, S., Mastromatteo, M., Di Giulio, S.,
Attanasio, M., and Del Nobile, M. A. (2008) Effect of chitosan on the rheological and sensorial characteristics of apulia spreadable cheese. J. Dairy Sci. 91, 4155-4163.

18. Guilbert, S. (1986) Technology and application of edible protective films in food packaking and preservation theory and practise. Mathlouthi M. (ed).

19. Gulec, F., Bayram, M., Yıldırım, M., and Yıldrım, Z. (2004) Some properties of kaşar cheese coated with casein, Süleyman Demirel University, Recent Developments In Dairy Science and Technology, International Dairy Symposium. May 24-28. pp. 58-66.

20. Gokmen, M. and Gurbuz, U. (2011) Use of Chitosan in turkish sausage (Sucuk) productionand effects on quality. Kafkas. Univ. Vet. Fak. Der. p. 17.

21. Hayaloglu, A. A. (2009) Volatile composition and proteolysis in traditionally produced mature Kashar cheese. Int. J. Food Sci. Technol. 44, 1388-1394.

22. International Dairy Federation. (1993) Milk: Determination of the Nitrogen (Kjeldahl Method) and Calculation of the Crude Protein Content. IDF Standard 20B. Brussels: International Dairy Federation.

23. Keser, O., and Bilal, T. (2010) Zeytin Sanayi Yan Ürünlerinin Hayvan Beslemede Kullanım Olanakları. Lalahan Hay. Araşt. Ens. Derg. 50, 41-52.

24. Kester, J. J. and Fennema, O. R. (1986) Edible films and coatings: a review. Food Technol. 40: 47.

25. Koburger, J. A. and Marth, E. H. (1984) Yeasts and moulds. In: Marvin L. Speck (Editor), Compendium of Methods for the Examination of Foods A.P.H.A., Washington D.C., pp. 197-202.

26. Kousta, M., Mataragas, M., Skandamis, P., and Drosinos, E. H. (2010) Prevalence and sources of cheese contamination with pathogens at farm and processing levels. Food Control 21, 805-815.

27. Krishna, A. C., Sathiyaraj, M., Saravanan, R. S., Chelladurai, R., and Vignesh, R. (2012) A novel and rapid method to determine doxycycline in human plasma by liquid chromatography tandem mass spectrometry. Indian J. Pharm. Sci. 74, 541.

28. Kristo, E., Koutsoumanis, K. P., and Biliaderis, C. G. (2008) Thermal, mechanical and water vapor barrier properties of sodium caseinate films containing antimicrobials and their inhibitory action on Listeria monocytogenes. Food Hydrocolloid. 22, 373-386.

29. Krochta, J. M. and De Mulder-Johnston, C. (1997) Edible and biodegradable polymer films: Challenges and opportunities. Food Technol. 51, 61-74.

30. Kuchroo, C. N. and Fox, P. F. (1982) Soluble nitrogen in cheese: Comparison of extraction procedures. Milchwissenschaft 37, 331-335.

31. Kurita, K. (2001) Controlled functionalization of the polysaccharide chitin. Prog. Polym. Sci. 26, 1921-1971.

32. Kurt, A., Cakmakci, S., and Caglar, A. (2007) A guide book of analysis methods of milk and milk products. Turkey: Ataturk University, Agriculture Faculty, Erzurum, Turkey.

33. Liu, X. F., Guan, Y. L., Yang, D. Z., Li, Z., and Yao, K. D. 
(2001) Antibacterial action of chitosan and carboxymethylated chitosan. J. Appl. Poly. Sci. 79, 1324-1335.

34. Lucera, M., Mastromatteo, M., Conte, A., Zambrini, A. V., Faccia, M., and Del Nobile, M. A. (2014) Effect of active coating on microbiological and sensory properties of fresh mozzarella cheese. Food Pack. Shelf Life 1, 25-29.

35. Mei, J., Yuan, Y., Wu, Y., and Li, Y. (2013) Characterization of edible starch-chitosan film and its application in the storage of Mongolian cheese. Int. J. Biol. Macromol. 57, 17-21.

36. Ollé Resa, C. P., Gerschenson, L. N., and Jagus, R. J. (2013) Effect of natamycin on physical properties of starch edible films and their effect on Saccharomyces cerevisiae activity. Food Bioproc. Technol. 6, 3124-3133.

37. Ollé Resa, C. P., Jagus, R. J., and Gerschenson, L. N. (2014) Natamycin efficiency for controlling yeast growth in models systems and on cheese surfaces. Food Control 35, 101-108.

38. Ozdemir, S. and Sert, S. (1996). Gida Mikrobiyolojisi Tatbikat Notları. Atatürk Üniversitesi Ziraat Fakültesi Yayınlar1, Erzurum, No.128, p.111.

39. Polychroniadou, A., Michaelidou, A., and Paschaloudis, N. (1999) Effect of time, temperature and extraction method on the trichloroaceticacid-soluble nitrogen of cheese. Int. Dairy J. 9, 559-568.

40. Pranoto, Y., Salokhe, V. M., and Rakshit, S. K. (2005). Physical and antibacterial properties of alginate-based edible film incorporated with garlic oil. Food Res. Int. 38, 267-272.

41. Rabea, E. I., Badawy, M. E. T., Stevens, C. V., Smagghe, G., and Steurbaut, W. (2003) Chitosan as antimicrobial agent: Applications and mode of action. Biomacromol. 4, 1457-65.

42. Ramos, O., Silva, S., Soaresa, J., Fernandesa, J., Pocasa, M., and Pintadoa, M., et al. (2012) Features and performance of edible films, obtained from whey protein isolate formulated with antimicrobial compounds. Food Res. Int. 45, 351-361.

43. Rhoades, J. and Roller, S. (2000) Antimicrobial actions of degraded and native chitosan against spoilage organisms in lab- oratory media and foods. Appl. Environ. Microbiol. 66, 80-86.

44. Sarıolu, T. and Oner, Z. (2006) Usage possibilities of an edible filmfor coating Kashar cheese and its effects on cheese quality. Food 31, 3-10.

45. SAS (1998) Changes and Enhancements through Release 6.12, SAS Institute Inc., Cary, N.C., U.S.A.

46. Savello, P. A., Ernstrom, C. A., and Kalab, M. (1989) Microstructureand meltability of model process cheese made with rennet and acidcasein. J. Dairy Sci. 72, 1-11.

47. Sert, D., Ayar, A., and Akın, N., (2007) The effects of starter culture on chemical composition microbiological and sensory characteristics of Turkish Kashar cheese during rripening. Int. J. Dairy Technol. 60, 245-252.

48. Torlak, E. and Nizamoglu, M. (2011) Uçucu yăg 1çeren yenilebilir kitosan filmlerinin Staphylococcus aureus ve Escherichia coli O157:H7 üzerine etkinlikleri. Kafkas Univ. Vet. Fak. Der. 17(Suppl A), S125-S129.

49. Ture, H., Eroglu, E., Ozen, B., and Soyer, F. (2011) Effect of biopolymers containing natamycin against Aspergillus niger and Penicillium roquefortii on fresh kashar cheese. Int. J. Food Sci. Technol. 46, 154-160.

50. Wang, G. H. (1992) Inhibition and inactivation ollive species ol foodborne pathogens by chitosan. J. Food Prot. 55, 916925.

51. Yıldırım, M., Gulec, F., Bayram, M., and Yıldırım, Z. (2006) Propertiesof Kashar cheese coated with casein as a carrier of natamycin. Ital. J. Food Sci. 18, 127-138.

52. Y1lmaz, F. and Dagdemir, E. (2012) The effects of beeswax coating on quality of Kashar cheeseduring ripening. Int. $J$. Food Sci. Technol. 47, 2582-2589.

53. Zhong, Y., Cavender, G., and Zhao, Y. (2014) Investigation of different coating application methods on the performance of edible coatings on Mozzarella cheese. LWT-Food Sci. Technol. 56, 1-8. 